\title{
Application and Evaluation of the Performance of Poly (Vinyl Alcohol) and its Blend with Nitrocelulose in Leather Top Coating
}

\author{
Sani M. Gumel and Bello B. Dambatta
}

\begin{abstract}
A 5\% aqueous solution of polyvinyl alcohol (PVA) (m.wt. 125, 000), nitrocellulose and PVA/nitrocellulose blend were applied as a topcoat on dyed goatskin leather. The FT-IR spectroscopy of the cast polymer films indicated that each of the films in dry state consist of only pure polymer. The microscopic and physical characteristics of the coatings were also determined. The PVA coatings were found to have a glossy appearance, smooth handle and good extensibility, with excellent rubbing fastness and light fastness properties. However, the coatings have only a moderate adhesion of finish and have poor heat fastness and flexing endurance properties. The properties were found to improve when PVA was used in blend with nitrocellulose emulsion. The nitrocellulose coatings were, however, found to exhibit an almost all round superior coating property.
\end{abstract}

Index Terms-Performance, polyvinyl alcohol, nitrocellulose, leather, coating.

\section{INTRODUCTION}

The constant search for improved quality finishes and for maximum utilization of the finish applied have resulted in many changes in the finishing of leather. The changes in technology and development have gone from lacquers (all organic solvents) and a lacquer emulsion (moderate level solvents) to water borne (i.e. low level of organic solvents) finishes [1]-[3]. Truly water borne topcoats come from a variety of chemical substances, i.e. acrylics, urethanes, butadienes, vinyl resins, etc [4]-[6]. The purpose of these resins in the finish is to bind the leather pigment particles, give adhesion to the leather, impart flexibility so that the finish can be stretched with the leather, and also to protect the leather surfaces. For example, nitrocellulose is widely used in leather topcoat because it can be applied by a simple process (without any fixation) to yield a good transparent film finish on the leather, which is water resistant, washable, readily cleanable, very fast to rubbing, dirt-repellent and resistant to mechanical stressing[4], [5], [7]-[9]. From the results of our investigation on nitrocellulose coatings on leather the coatings have very good dry rub fastness and light fastness properties but only moderate wet rub fastness and poor heat fastness properties. The adhesion of the finish, light fastness of the coloured coated leather, the flexing endurance, the dry rub fastness and the heat fastness properties of the top coated leather all improved when a suitable ultraviolet stabilizer is

Manuscript received April 3, 2013; revised June 3, 2013

S. M. Gumel is with the Department of Pure and Industrial Chemistry, Bayero University, Kano, P.M.B 3011, Kano. Nigeria (e-mail: Sani_gumel@yahoo.com). incorporated into the coating [10], [11].

Polyvinyl alcohol has very good film-forming properties like nitrocellulose. The PVA film has a very high tensile strength and toughness and is widely used as adhesive, in paper coating, textile warp sizing and finishing applications [12], [13]. Despite the outstanding properties of PVA it does not seem to have been exploited for application in leather top coating [14]. In this communication we report the results of our investigation and assessment of the role of PVA as a topcoat for leather. The significance of the PVA/nitrocellulose blend in leather topcoat was also examined.

\section{Materials And MethodS}

\section{A. Polymeric Materials and Leather Sample}

Polyvinyl alcohol is produced by the manufacturers by the hydrolysis of a polyvinyl ester as vinyl alcohol does not exist in the free state, and in practice polyvinyl acetate is used [15], [16]. Various grades of PVA are available which differ in molecular weight and in the residual acetate content [17]. The presence of hydroxyl groups attached to the main chain has a number of significant effects including the fact that the polymer is hydrophilic and dissolves in water to a greater or lesser extent according to the degree of hydrolysis and the temperature. In this work a 5\% aqueous solution of PVA (ex BDH Ltd.) of molecular weight 125,000 was prepared in freshly distilled water and used.

The nitrocellulose emulsion was prepared as described earlier by Dambatta and co-workers [10]. Blend of the two polymers were prepared by mixing the appropriate proportions of the PVA solution and nitrocellulose emulsion followed by vigorous stirring to ensure a homogeneous and stable mixture.

\section{B. Film Preparation:}

Films of PVA, nitrocellulose and PVA/nitrocellulose blends were cast on glass plates in accordance with the procedure described in our earlier communication [10]. A doctor blade was then used to spread the liquid drops along the plate length with a gap of about $400-500 \mu \mathrm{m}$ to generate films of $122-150 \mu \mathrm{m}$ in thickness on drying. The spread films were left to dry at room temperature to form a film of uniform thickness on the glass. The glass that had been coated with the film was quenched in water at $25^{\circ} \mathrm{C}$ so as to disengage the film from the glass plate. The separated film was finally air-dried. 


\section{Preparation and Top Coating of the Leather}

Tanned and dyed goatskin leather samples were used in this work. The tanning and dyeing was done at Intertan Ltd [18]. A dried wet blue chrome goatskin that had been re-chromed and neutralised prior to drying was re-wetted and then readjusted to a $\mathrm{pH}$ of between 4.6 - 4.9 and dyed with $1 \%$ acid dye, Bruno Oroderm PT (CIBA GEIGY, ROHM and STOKHAUSE). A base coat which principally consists of pigments, binders and auxiliaries was then prepared by the addition of the appropriate auxiliaries and binder to the pigment mix. Typically, 100g Earnshaw powder Tgi, $60 \mathrm{~g}$ aqueous filler, $500 \mathrm{~g}$ water and $200 \mathrm{~g}$ Earnshaw Encryl-N were added in the order as listed into $200 \mathrm{~g}$ pigment mix. The mixture was vigorously stirred after each addition. The base coat was then applied on to the dyed leather sample first as two coats by padding followed with another two coats by spraying. Each coat application was followed with air-drying and then machine drying, respectively. The dried samples were hot plated on a steam heated hydraulic press at an application pressure of $100 \mathrm{kgcm}^{-2}$. Separate samples of the bottom coated leather were top, coated with PVA solution, nitrocellulose emulsion and their blends, respectively. In each case, two coats of the finish were applied onto the bottom coated leather samples by single spraying and drying respectively. Finally, the coated samples were dried and hot plated as described above.

\section{Characterization of the Polymer Films and Coatings}

First, preliminary assessments for change in appearance, handle and extensibility were carried out on both the bottom coated leather and the top coated leather samples. The cast polymer films and their coatings on the leather were characterized by Fourier Transform Infrared (FT-IR) Spectroscopy and Scanning Electron Microscopy (SEM), with a Perkin-Elmer 1740 FT-IR spectrophotometer and a JEOL JSM 820 scanning electron microscope, respectively, following essentially the same techniques as earlier described [19]-[21]. The top coated coloured leather samples were also subjected to physical tests for flexing endurance,

adhesion of finish, light fastness, dry and wet rubbing fastness and heat fastness properties following the Society of Leather Trades' Chemists (SLTC) methods [22].

\section{RESUlTS AND DisCUSSION}

The FT-IR spectra of the films of nitrocellulose, polyvinyl alcohol and 50/50 nitrocellulose/polyvinyl alcohol blend are shown in Fig. 1 as (a), (b) and (c), respectively and the respective absorption frequencies in cm-' are given in Table I. In the nitrocellulose spectra there is an -O-H stretching vibration peak at $3459 \mathrm{~cm}^{-1}$, which corresponds to intermolecular hydrogen bonding. This is due to the residual $-\mathrm{OH}$ groups that are present in the polymer in line with the literature report that the degree of nitration of cellulose to nitrocellulose is partial with a degree of nitration of about 1.9 in the nitrocellulose leaving a residual hydrogen content of about $13 \%$ in the nitrocellulose [19]. A unique feature in the spectrum of PVA (Fig. 1b) is the common -O-H stretching vibration at $3375 \mathrm{~cm}^{-1}$. Other prominent bands are the $\mathrm{C}-\mathrm{H}$ stretching at $2930 \mathrm{~cm}^{-1}, \mathrm{C}-\mathrm{H}$ deformation at $1487 \mathrm{~cm}^{-1}$ and
$\mathrm{C}-\mathrm{O}$ stretching at $1103 \mathrm{~cm}^{-1}$. The carbonyl $(\mathrm{C}=\mathrm{O})$ peak at $1702 \mathrm{~cm}^{-1}$ is ascribed to the residual poly (vinyl acetate) in the polymer chain [15]. The spectrum of the film cast from the 50/50 blend of nitrocellulose/polyvinyl alcohol blend (Fig. lc) shows an - O-H stretching at $3311 \mathrm{~cm}^{-1}$, a C-H stretching at $2932 \mathrm{~cm}^{-1}$ and a C-O stretching at $1034 \mathrm{~cm}^{-1}$, which are all common peaks expected in both nitrocellulose and poly(vinyl alcohol) [19]. Others are $\mathrm{C}-\mathrm{NO}_{2}$ absorption at $1277 \mathrm{~cm}^{-1}$ expected in nitrocellulose and $\mathrm{O}-\mathrm{N}=\mathrm{O}$ and $\mathrm{C}=\mathrm{O}$ peaks at $1646 \mathrm{~cm}^{-1}$ and $1719 \mathrm{~cm}^{-1}$ expected in nitrocellulose and polyvinyl alcohol, respectively, with the later being due to the trace amount of polyvinyl acetate [13]. The visual appearance of the 50/50 blend film together with the result of its FT-IR spectrum indicates the formation of a stable homogeneous physical blend of the two polymers.

The SEM micrographs of the leather samples top coated with nitrocellulose PVA, nitrocellulose/PVA blend and that for the bottom coated leather are shown in Fig. 2. The micrographs generally indicate very good cover-ups of, in particular, the convolution (in the bottom coated leather surface) with all the finishes used. Even though the cover-up exhibited by the PVA coating was not as good as that of nitrocellulose, perhaps due to the higher viscosity of the former, improvement was achieved as a result of its blending with nitrocellulose, which is a softer and more compact topcoat.

Polyvinyl alcohol was found to have a poor flexing endurance property as shown in Table II. The PVA leather sample exhibited creases and poor break at as low as 2000 flexes, particularly when compared with the outstanding performance shown by nitrocellulose, which did not show any effect at up to 20,000 flexes. The excellent break exhibited by the nitrocellulose may be as a result of its dimensional stability and toughness coupled 'with its excellent sealing and fixation property to the bottom finishes as explained by previous workers [23], [24]. A remarkable improvement in flexing property is however, recorded with PVA when in blend with nitrocellulose. The results of the adhesion of finish property of the top coated leather samples, Table III, shows that PVA have a moderate adhesion when compared to that of nitrocellulose, which has already been plasticed [25]. As may be observed, there is a general improvement in adhesion of finish of PVA when used in blend with nitrocellulose. This is in line with earlier observation that results obtained on blending of polymers were averaged according to blend composition [10].

The influence of topcoat on the light fastness property of finished coloured leather is clearly shown in Table III. It could be observed that the light fastness property improved from average value (i.e. 4), on the bottom coated leather, to an excellent grade with the application of the topcoat. This observation was already made by Brown [26] that "even though light fastness is affected not only by the dye (an acid dye in this case) but also by retannage and fat liquors, it can be improved by the use of pigment in the topcoat;" and it can also be improved by the topcoat alone [4], [5], [27]. The relatively inferior light fastness property shown by PVA may perhaps be due to its light transmitting property as observed by Guthrie (Guthrie J.T, Department of Colour Chemistry, Univ. of Leeds, Leeds, U.K, Personal communication). 
TABLE I: FT-IR ABSORPTION FREQUENCIES (CM-1) OF NITROCELLULOSE, PVA AND 50/50\% PVA/ NitROCELLULOSE BLEND

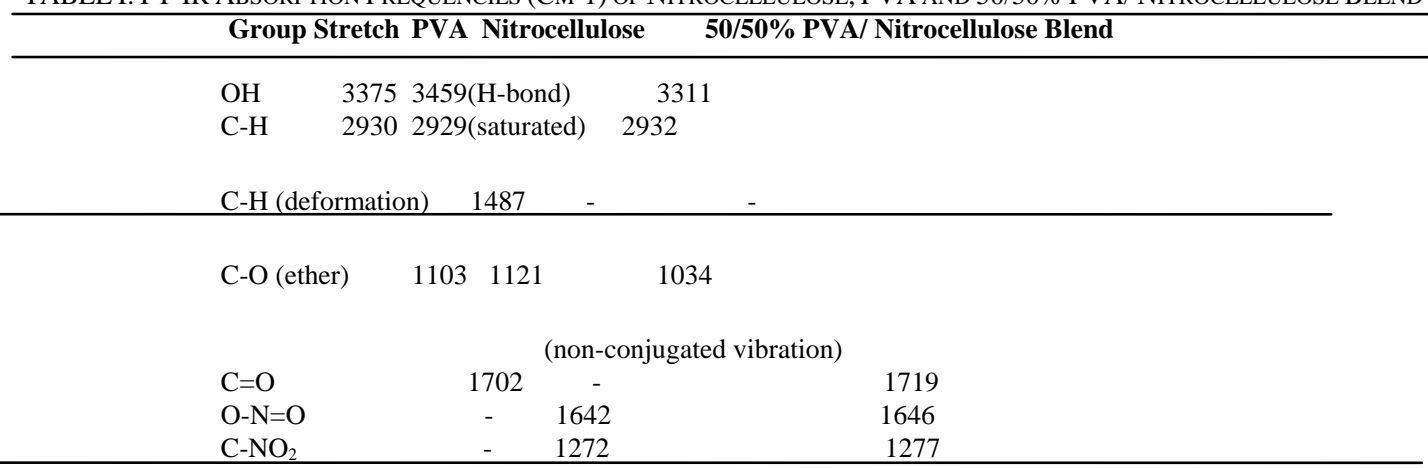

TABLE II: FleXING ENDURANCE OF Light LEATHER SURFACE FinISHED with NitrocelluLOSE PVA AND 50/50\% PVA/ NitrocELLULOSE BLEND

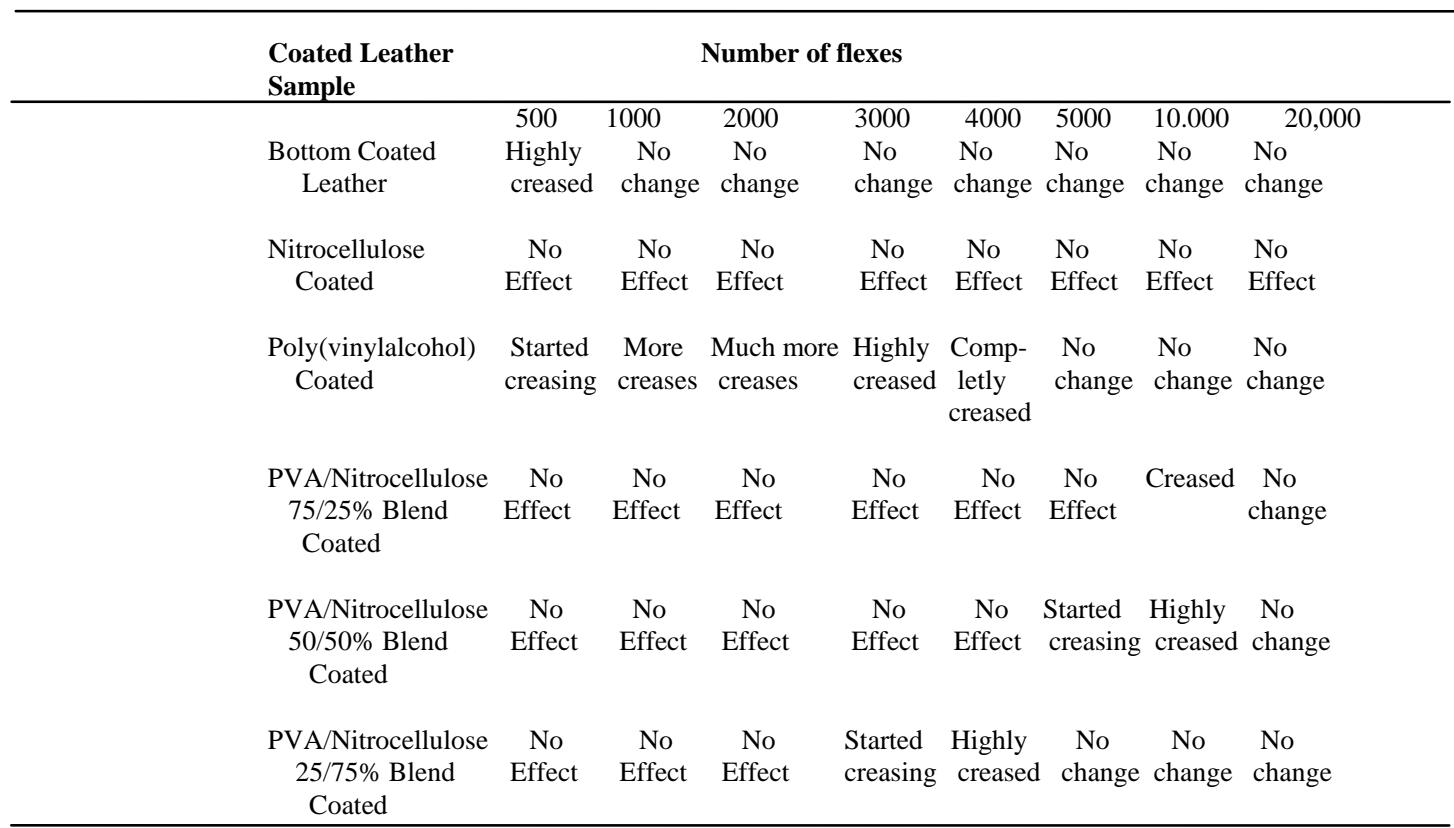

TABLE III: AdHESION OF Finish, Light FASTNESS ANd Rubbing FASTNESS OF Nitrocellulose, PVA AND 50/50\% BLEND OF PVA/NitrocelLuLOSE

\begin{tabular}{|c|c|c|c|c|}
\hline \multirow{2}{*}{\begin{tabular}{l} 
Coated Leather \\
Sample \\
\cline { 2 - 2 }
\end{tabular}} & \multirow{2}{*}{$\begin{array}{c}\begin{array}{c}\text { Adhesion of } \\
\text { Finish }\end{array} \\
\begin{array}{c}\text { Peeling Load } \\
\text { (g/cm) }\end{array} \\
\end{array}$} & \multirow{2}{*}{$\begin{array}{c}\text { Light } \\
\text { Fastness }\end{array}$} & \multicolumn{2}{|c|}{ Rubbing Fastness } \\
\hline & & & Dry & Wet \\
\hline Bottom Coated & - & 4 & $\begin{array}{l}\text { Rubbed at } 50 \\
\text { Rubbing } \\
\text { Cycles }\end{array}$ & $\begin{array}{l}\text { Rubbed at } 20 \\
\text { Rubbing } \\
\text { cycles }\end{array}$ \\
\hline $\begin{array}{l}\text { Nitrocelulose } \\
\text { Coated }\end{array}$ & 300 & 8 & $\begin{array}{l}\text { No effect up } \\
\text { to } 1000 \\
\text { Rubbing } \\
\text { Cycles }\end{array}$ & $\begin{array}{l}\text { Rubbed at } 100 \\
\text { Rubbing } \\
\text { Cycles }\end{array}$ \\
\hline PVA Coated & 203 & $7-8$ & $\begin{array}{l}\text { No effect up } \\
\text { to } 1000 \\
\text { Rubbing } \\
\text { cycles }\end{array}$ & $\begin{array}{l}\text { No effect up } \\
\text { to } 300 \\
\text { Rubbing } \\
\text { cycles }\end{array}$ \\
\hline $\begin{array}{l}75 / 25 \% \\
\text { PVA/Nitrocellulose } \\
\text { Coated }\end{array}$ & 290 & 8 & $\begin{array}{l}\text { No effect up } \\
\text { to } 1000 \\
\text { Rubbing } \\
\text { Cycles }\end{array}$ & $\begin{array}{l}\text { Rubbed at } \\
200 \\
\text { Rubbing } \\
\text { Cycles }\end{array}$ \\
\hline $\begin{array}{c}50 / 50 \% \\
\text { PVA/Nitrocellulose } \\
\text { Coated }\end{array}$ & e & 8 & $\begin{array}{l}\text { No Effect up } \\
\text { to } 1000 \\
\text { Rubbing } \\
\text { Cycles }\end{array}$ & $\begin{array}{l}\text { No Effect up } \\
\text { to } 300 \\
\text { Rubbing } \\
\text { Cycles }\end{array}$ \\
\hline $\begin{array}{c}25 / 75 \% \\
\text { PVA/Nitrocellulose } \\
\text { Coated }\end{array}$ & 240 & 8 & $\begin{array}{l}\text { No Effect up } \\
\text { to } 1000 \\
\text { Rubbing } \\
\text { Cycles }\end{array}$ & $\begin{array}{l}\text { No effect } \\
\text { up to } 300 \\
\text { rubbing } \\
\text { Cycles }\end{array}$ \\
\hline
\end{tabular}


TABLE IV: HeAt FASTNESS PROPERTY OF COLORED LEATHER COATED WITH Nitrocellulose, PVA AND 50/50\% PVA NitRoCELLULOSE BLEND

\begin{tabular}{|c|c|c|c|c|c|}
\hline \multirow{2}{*}{$\begin{array}{l}\text { Coated Leather } \\
\text { Sample }\end{array}$} & \multirow[b]{2}{*}{110} & \multicolumn{2}{|c|}{ Temperature $\left({ }^{\circ} \mathrm{C}\right)$} & \multirow[b]{2}{*}{170} & \multirow[b]{2}{*}{200} \\
\hline & & 130 & 150 & & \\
\hline Bottom Coated & No Effect & No Effect & No Effect & No effect & $\begin{array}{l}\text { Started } \\
\text { Darkening }\end{array}$ \\
\hline $\begin{array}{l}\text { Nitrocellulose } \\
\text { Coated }\end{array}$ & No Effect & $\begin{array}{l}\text { Becomes } \\
\text { Shiner }\end{array}$ & $\begin{array}{l}\text { Started } \\
\text { Darkening }\end{array}$ & Completely & $\begin{array}{l}\text { Started } \\
\text { Burning }\end{array}$ \\
\hline PVA Coated & No Effect & Started & Much & Completely & Started \\
\hline $75 / 25 \%$ & & Darkening & Darker & Darker & Burning \\
\hline $\begin{array}{l}\text { PVA/Nitrocellulose } \\
\text { Coated } \\
50 / 50 \%\end{array}$ & No Effect & $\begin{array}{l}\text { Becomes } \\
\text { Duller }\end{array}$ & $\begin{array}{l}\text { Much } \\
\text { Darker }\end{array}$ & $\begin{array}{l}\text { Completely } \\
\text { Darkened }\end{array}$ & $\begin{array}{l}\text { Started } \\
\text { Burning }\end{array}$ \\
\hline $\begin{array}{l}\text { PVA/Nitrocellulose } \\
\text { Coated } \\
25 / 75 \%\end{array}$ & No Effect & $\begin{array}{l}\text { Started } \\
\text { Darkening }\end{array}$ & $\begin{array}{l}\text { Much } \\
\text { Darker }\end{array}$ & $\begin{array}{l}\text { Completely } \\
\text { Darkened }\end{array}$ & $\begin{array}{l}\text { Started } \\
\text { Burning }\end{array}$ \\
\hline $\begin{array}{l}\text { PVA/Nitrocellulose } \\
\text { Coated }\end{array}$ & No Effect & $\begin{array}{l}\text { Started } \\
\text { Darkening }\end{array}$ & $\begin{array}{l}\text { Much } \\
\text { Darker }\end{array}$ & $\begin{array}{l}\text { Completely } \\
\text { Darkened }\end{array}$ & $\begin{array}{l}\text { Started } \\
\text { Burning }\end{array}$ \\
\hline
\end{tabular}

The dry and wet rubbing tests (Table III) shown by the bottom coated leather were invariably poor which has earlier been attributed by Gill and Shaw [28] to the presence of some non-binding materials such as pigments and various water sensitive materials. As is the purpose of application of topcoats to form a smooth, continuous film protecting the bottom an improvement in both the dry and wet fastness properties were generally observed when the bottom coated leather was top coated with nitrocellulose, PVA and their blend, respectively. The moderate wet rub fastness property shown by nitrocellulose may be as a result of the presence of water sensitive materials (e.g. Surface Active Agents (SAA's)) in the topcoat [1].

From the result in Table IV, there isn't any effect of heat observed on the bottom coated leather up till a temperature of $200^{\circ} \mathrm{C}$ where it started darkening. However, an inferior heat fastness property was observed by application of nitrocellulose, PVA and their blend as topcoats. The lower heat fastness property exhibited by nitrocellulose agreed with observation made by Mudd (in Gumel) [19] and, as also observed by Dambatta et al, [10] that "nitrocellulose finishes are sensitive to heat such that darkening could occur". When PVA is heated above a temperature of $120^{\circ} \mathrm{C}$, water is eliminated to give conjugated double bonds, which impart colour.

It can be concluded that leather topcoats of satisfactory performance were formed by polyvinyl alcohol when compared with the traditionally used nitrocellulose. The ruband light fastness properties of the coatings were very good, with however, low flexing endurance and adhesion of finish properties caused by its rigidity. The inferior flexing endurance and adhesion of finish were found to improve when the PVA is used in blend with nitrocellulose. The heat fastness property of PVA coating was generally poor like that of the nitrocellulose. Since incorporation of plasticizers in the finish were established to have remarkably improved the flexing and adhesion properties, for example, nitrocellulose, it is very likely that addition of suitable plasticizers in PVA finish would lead to a similar effect. It is recommended, therefore that, this should be thoroughly examined.
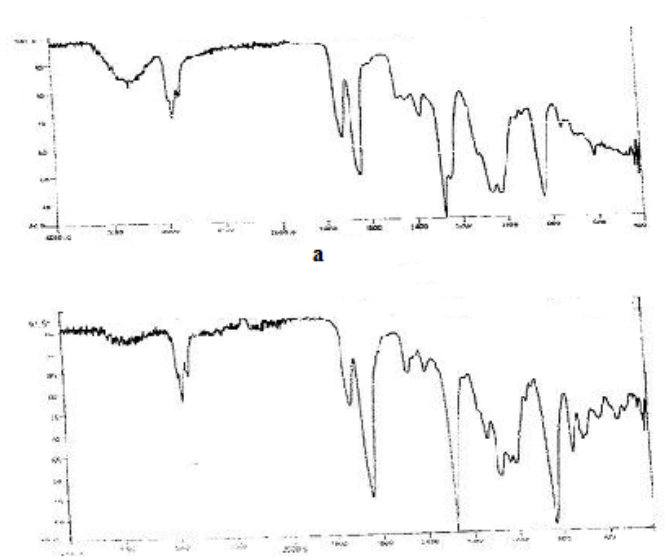

b

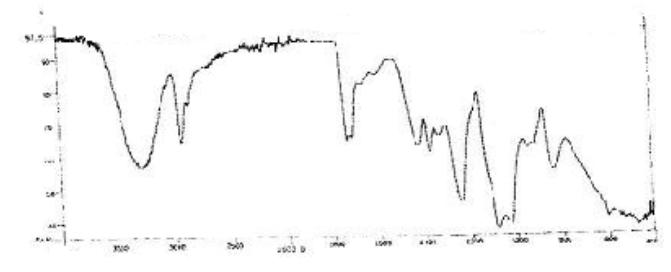

c

Fig. 1. FTIR spectra of a) nitrocellulose film b) polyvinyl alcohol film and c) $50 / 50$ blend nitrocellulose/polyvinyl alcohol film.

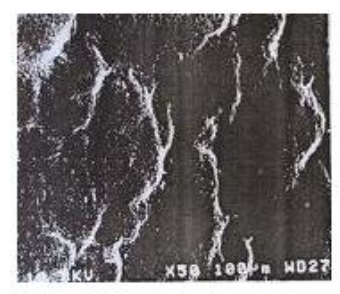

a

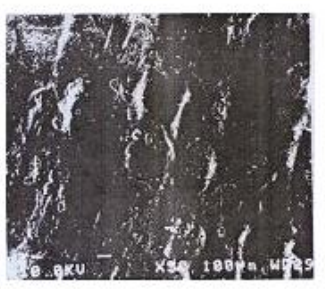

c

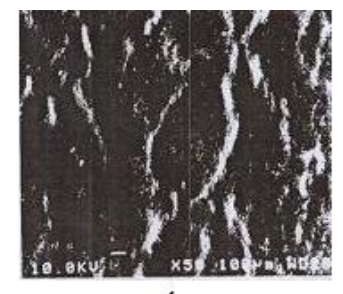

$\mathrm{b}$

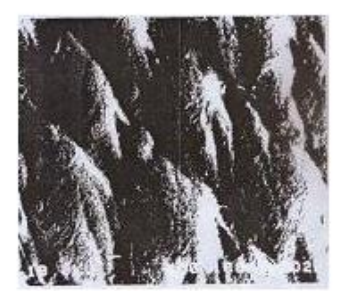

d
Fig. 2. Scanning electron micrographsof coated leather samples a) nitrocellulose topcoated b) polyvinyl alcohol top coated c) 50/50 blend nitrocellulose/polyvinyl alcohol top coated d) bottom coated 


\section{APPENDIX}

Appendixes, if needed, appear before the acknowledgment.

\section{ACKNOWLEDGEMENTS}

We wish to express our gratitude to the British Council, Kano, International Tanners (INTERTAN) Ltd; Kano, Great Northern Tanning Company Ltd; Kano. College of Chemical and Leather Technology, Zaria, Earnshaw Ltd. of Northallerton, UK and the Department of Colour Chemistry of University of Leeds.

\section{REFERENCES}

[1] C. J. Gill, "Improving the performance of aqueous topcoats-Technical Note," J. Amer Leather Chem Assoc, vol. 88, pp. 197-206, 1993

[2] T. Ramasani, J. R. Rao, N. K. C. Babu, K. Parthasarathi, P. G. Rao, P. Saravana, R. Gayathri, and J. K. Sreeram, "Beamhouse and tanning operations: Process Chemistry revisited," J. Soc Leather Tech. Chem. vol. 83, no. 1, pp. 39-44, 1999.

[3] History and Process of Leather. (2012). Retrieved June, 10, 2012 from INTERTAN. International Tanners Ltd. Phase 1, Sharada Industrial Estate, Kano. [Online]. Available: http://www.contractleathers.com/History and process.pdf

[4] A. G. Bayer, Tanning, Dyeing and Finishing, $4^{\text {th }}$ edn (Geschaft-bereich Ferben, 5090 Leverrkusen), pp. 156-229, 1986

[5] Basf, Pocket Book for the Leather Technologist, $3^{\text {rd }}$ end (Basf 67056 Ludwigshafer, Germany), pp. 194-233, 1995.

[6] The Leather Manufacturing Process (2012). [Online]. Available: http://www.en.wikipedia.org/wiki/Leather- production process

[7] J. H. Sharphouse, Leather Technicians Handbook (Buckland Press Ltd, London), pp. 76-227, 1971.

[8] B. K. Sharma, Industrial Chemistry Including Chemical Engineering, 16th Edition, Goel Publishing house, India. pp. 1367-1370, 2011

[9] Nitrocellulose (Chemical Compound). (2013). [Online]. Available: http://www.britannica.com/EBchecked/topic/416152/nitrocellulose

[10] B. B. Dambatta, S. M. Gumel, and J. T. Guthrie, "Investigation of the role of some ultraviolet absorbers in the stabilisation of nitrocellulose topcoat in leather," J. Soc Leather Trade Chemists vol. 92, pp. 314-322, 2008.

[11] R. U. Arinze, A. N. Eboatu, P. A. Okoye, and C. Onwukeme, "Establishing polymer-polymer interaction by meanst of $\mathrm{T}_{\mathrm{m}}$ studies, Nig," Journ of Sci Techol, vol. 7, no. 1, pp. 79-84, 2011.

[12] S. M. Gumel, S. Habibu, M. Ladan, and A. H. Birniwa, "Application of Polyvinyl Alcohol in the deying of cotton with direct dyes," International Science and Technology Conference (ISTEC), SAKARYA University, Dubai 2012 (in press)

[13] Polyvinyl Alcohol (Chemical Compound). (2013). [Online]. Available: http://www.britannica.com/topic/469236/polyvinyl alcohol

[14] Dupont ${ }^{\mathrm{tm}}$ Elvano $^{\circledR}$ Polyvinyl Alcohol. (2013). [Online]. Available: http://www. 2.dupont.com/Elvano/en_US

[15] S. M. Gumel, M. K. Yakubu, and U. A. Busuguma, "Study on the use of crosslinked polyvinyl alcohol as a crease/wrinkle resistance finish on cotton fabric," Int. Journ of Sci Tech Res, 2012.

[16] Polyvinyl Alcohol- Process, Properties, Technology. (2012). [Online]. Available: alcohol.htm
[17] C. T. Thomas, Practical Leather Technology (Robert Krieger Publishing Co., Florida) pp. 238-262, 1985.

[18] Leather- Wikipedia, the free encyclopedia. (2012). [Online]. Available: http://www.en.wikipedia.org/wiki/leather

[19] S. M. Gumel, Studies on the Surface Finishing of Leather Using Some Commercial and Novel Polymers, Ph. D dissertation, dept. of chemistry, Bayero University, Kano, Nigeria, 2001

[20] Z. Bajza, J. Posaric, and N. Sugnetic, "Application of FT-Infraredspectroscopy to the study of structural changes of leather during tannery prcocesing," J. Soc. Leather Trade's Chemists, vol. 81, pp. 219-223, 1998.

[21] L. Dietrich, "Waterborne coatings based on different film- forming polymers," J. Amer. Leather Chem Assoc, vol. 83, pp. 87-94, 1988.

[22] SLTC, Official Methods of Analysis $6^{\text {th }}$ edn, (Sociaty of Leather Trades Chemist (SLTC), Redbourn, Herts), 1996.

[23] Nitrocellulose- Wikipedia, the free encyclopedia. (2012). [Online]. Available: http://www.en.wikipedia.org/wiki/Nitrocellulose

[24] Nitrocellulose - Dow Chemical Corporate Website. (2012). [Online]. Available: http://www.dow.com//..../polymers/nitrocellulose/index.htm

[25] P. Earnshaw, Leather Finishing Formulations, Earnshaw Ltd., Northallerton, UK, 1998.

[26] S. G. Brown, "The making and Colouration of Leather," J. Soc. Dyers Colours, vol. 110, pp. 213-214, 1994

[27] Tanning and Leather Finishing- International Labor Organisation. (2013). [Online]. Available: http://www..ilo.org/safework_bookshelf/english?content\&nd=857171 045

[28] R. Shaw, Leather Finishing, in Chemistry and Technology of Leather edited by F. O. Flaharty, M. L. Rovert, and T. R. William, Robert Krieger Publishing Co., New York, pp. 194-221, 1978

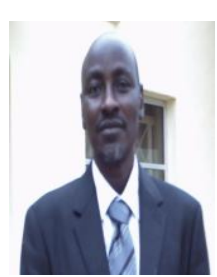

S. M. Gumel was born in Gumel, Jigawa State, Nigeria, 1964. Graduated in Textile Science and Technology (1988) at the Ahmadu Bello University, Zaria, Nigeria and gained his Ph.D in Polymer Science (2001) at Bayero University, Kano, Nigeria, following a Masters degree in Colour Chemistry (1995) from the same university. He worked as Industrial Officer with the Kano and Jigawa State Governments, respectively (1989 - 1995). Has been lecturing, since 1995 at the Bayero University, Kano and is currently an Associate Professor in the Department of Pure and Industrial Chemistry. He was variously a Head of Department in BUK and the Department of Chemical Sciences, Federal University Kashere, Nigeria and is presently (First, on sabbatical and Later special official appointment) the Dean, Faculty of Science at the Federal University Kashere. He has published in Journal of the Soc. of Leather Technologists and Chemists, Journal of Reinforced Plastics and Composites and Advances in Chemical Engineering and Sciences among others. Currently, he is mainly involved in the development of natural colourants and other eco- friendly dyes, polymeric surface coating, and coloured effluents treatment.

Sani M. Gumel is a member to the following Professional Bodies; Chemical Socieaty of Nigeria, Textile Association of Nigeria, Institute of chartered Chemists of Nigeria, Polymer Institute and a fellow of the Institute of Corporate Administration. 